\title{
Nilai-nilai dan metode pendidikan karakter di taman kanak- kanak di Banjarmasin
}

\author{
Dwi Siswoyo*, Rukiyati, L. Hendrowibowo \\ Fakultas Ilmu Pendidikan, Universitas Negeri Yogyakarta \\ *Corresponding Author. e-mail: dwi_siswoyo@uny.ac.id
}

\begin{abstract}
Abstrak
Tujuan penelitian ini adalah untuk menganalis nilai-nilai karakter yang menjadi target pendidikan karakter di Taman Kanak-Kanak di kota Banjarmasin, dan menganalisis metode penanaman nilai karakter yang diterapkan di taman kanak-kanak di kota Banjarmasin. Penelitian ini menggunakan pendekatan deskriptif kualitatif dengan metode pengumpulan data berupa diskusi grup terfokus (focus group discussion). Subjek penelitian ini terdiri dari 30 orang guru TK 'Aisyiyah di kota Banjarmasin. Analisis data mengikuti langkah-langkah Miles \& Huberman meliputi, reduksi data, penyajian data dan penarikan kesimpulan. Uji keabsahan data dengan trianggulasi sumber. Hasil penelitian menunjukkan bahwa ada delapan nilai utama yang dikembangkan guru, yaitu religiusitas, respek (hormat menghormati), kemandirian, percaya diri, kejujuran, disiplin, tanggung jawab, dan kerjasama. Metode yang digunakan guru adalah keteladanan, pembiasaan, memberi nasehat, bercerita dan sosiodrama, kunjungan sosial, fasilitasi, bernyanyi, pengenalan dan hafalan hadis singkat. Evaluasi pendidikan moral dilakukan sesuai yang tercantum di dalam kurikulum TK, yaitu menggunakan observasi perilaku anak sehari-hari. Sebagian besar anak telah mencapai perkembangan moral yang baik, dan beberapa anak mendapat nilai sangat baik. Perilaku moral yang paling tampak perkembangannya adalah kemandirian dan rasa percaya diri. Anak telah dapat membaca kitab suci Alquran, dan menghafal beberapa hadis pendek.
\end{abstract}

Kata kunci: karakter, pendidikan, anak usia dini, taman kanak-kanak, 'Aisyiyah

\begin{abstract}
The purpose of this study were to analyze the character values that are targeted for character education in kindergartens in the city of Banjarmasin, and analyze the method of character value inculcation that is applied in kindergartens in the city of Banjarmasin. This study used a qualitative descriptive approach with data collection methods in the form of focus group discussions. The subjects of this study consisted of 30 teachers of 'Aisyiyah kindergartens in the city of Banjarmasin. Data analysis follows the steps of Miles \& Huberman including, data reduction, data condensation, data display and conclusion drawing. The validity of the data used source triangulation. The results showed there were eight main values developed by the teacher, namely religiosity, respect, independence, confidence, honesty, discipline, responsibility, and cooperation. The methods used by the teacher were role model, habituation, giving advice, storytelling and sociodrama, social visits, facilitation, singing, introduction and memorization of short hadith. Evaluation of moral education were carried out according to kindergarten curriculum, which uses observations of children's daily behavior. Most children have achieved good moral development, and some children get very good grades. The most visible moral behavior development is respect, independence and self-confidence. The child has been able to read the Koran, and memorize some short hadiths.
\end{abstract}

Keywords: character, education, early childhood, kindergarten, 'Aisyiyah 


\section{PENDAHULUAN}

Undang-Undang Nomor 20 Tahun 2003 tentang Sistem Pendidikan Nasional menyebutkan di dalam pasal 3 bahwa pendidikan nasional berfungsi mengembangkan kemampuan dan membentuk watak serta peradaban bangsa yang bermartabat dalam rangka mencerdaskan kehidupan bangsa, bertujuan untuk mengembangkan potensi peserta didik agar menjadi manusia yang beriman dan bertaqwa kepada Tuhan yang Maha Esa, berakhlak mulia, sehat, berilmu, cakap, kreatif, dan menjadi warga negara yang demokratis serta bertanggung jawab. Berdasarkan pasal 3 UU Sisdiknas tersebut, dapat dikatakan bahwa pendidikan itu tidak hanya mendidik peserta didik untuk menjadi manusia yang cerdas, melainkan juga membangun kepribadiannya agar berkarakter luhur.

Pendidikan yang menghasilkan peserta didik berkarakter luhur tersebut masih jauh dari jangkauan, karena pendidikan di Indonesia lebih memprioritaskan kemampuan aspek kognitif, berusaha membentuk siswa yang cerdas, namun mengesampingkan aspek afektif. Dunia pendidikan kita telah memberikan porsi yang sangat besar untuk pengetahuan/kognitif, akibatnya pendidikan tersebut kurang menekankan aspek penanaman karakter, sehingga menimbulkan berbagai macam permasalahan dikalangan peserta didik. Hal tersebut terlihat dari berbagai masalah yang terus bermunculan sebagai akibat dari semakin menurunnya kualitas nilai-nilai karakter pada peserta didik. Peserta didik, khususnya anak TK lebih menonjol pada ke-aku-annya dibanding sifat sosialnya. Mereka kurang memperhatikan lingkungan, lebih asyik dengan permainannya yang berupa gadget. Peristiwa dan fenomena tersebut tentu sangat memprihatinkan bagi semua pihak terutama mereka yang mendambakan pendidikan yang baik.

Keadaan yang memprihatinkan sebagaimana tersebut, ditambah lagi dengan kekerasan yang terjadi dalam dunia pendidikan dan jika membaca data yang dirilis (KPAI, Oktober 2016), menunjukkan bahwa kasus kekerasan yang terjadi dalam dunia pendidikan dari tahun 2011 hingga 2016 sebanyak 2496 kasus. Kasus-kasus kekerasan di dunia pendidikan tersebut meliputi, anak korban tawuran pelajar sebanyak 363 siswa, anak pelaku tawuran pelajar sebanyak 441 siswa, anak korban kekerasan di sekolah (bullying) sebanyak 692 siswa, anak pelaku kekerasan di sekolah (bullying) sebanyak 449 siswa, dan anak korban kebijakan (pungli di sekolah, penyegelan sekolah, tidak boleh ikut ujian, anak putus sekolah, dan lain-lain) sebanyak 551 siswa.

Hal inilah yang mendesak pemerintah menempuh berbagai kebijakan, salah satunya Kebijakan Nasional Pembangunan Karakter 2005-2025. Kebijakan tersebut sebagai bentuk upaya pemerintah dalam menanggulangi degradasi moral yang terjadi saat ini. Pendidikan karakter dirasa perlu bagi semua kalangan tanpa terkecuali, pendidikan di tingkat TK.. Pembinaan karakter harus dikembangkan dalam pembelajaran di dalam kelas dan diinternalisasikan secara maksimal kepada peserta didik dalam dikehidupan sehari-hari, sebab itulah untuk mendapatkan pendidikan karakter yang berhasil tentunya harus didukung oleh semua pihak, baik itu orangtua, sekolah maupun masyarakat sekitar.

Internalisasi (proses dimana individu belajar dan diterima menjadi bagian dan mengikat diri dalam nilai-nilai tersebut) pendidikan karakter tersebut, sebaiknya dilakukan sejak dini yakni pada usia kanak-kanak atau yang biasa disebut dengan usia emas (golden age). Pendidikan karakter sejak dini pada anak diharapkan dapat menjadi bekal mereka ketika menginjak kehidupan selanjutnya. Adanya penanaman pendidilkan karakter secara sistematis dan berkelanjutan juga akan memberi dampak positif bagi perkembangan kecerdasan emosi seorang anak. Kecerdasan emosi inilah yang menjadi bekal bagi anak menyongsong kehidupannya kearah yang lebih baik di masa mendatang.

Thomas Lickona (1991) menggunakan istilah pendidikan karakter yang sebenarnya sama artinya dengan pendidikan nilai. Pendidikan karakter adalah upaya mengembangkan kebajikan sebagai fondasi dari kehidupan yang berguna, bermakna, produktif dan fondasi untuk masyarakat yang adil, penuh belas kasih dan maju. Selanjutnya, Lickona mengatakan bahwa karakter yang baik meliputi tiga komponen utama, yaitu : moral knowing, moral feeling, moral action. Moral knowing meliputi: sadar moral, mengenal nilai-nilai moral, perspektif, penalaran moral, pembuatan keputusan dan pengetahuan tentang diri. Moral feeling meliputi: kesadaran hati nurani, harga diri, empati, mencintai kebaikan, kontrol diri dan rendah hati. Moral action meliputi kompetensi, kehendak baik dan kebiasaan. Dapat disimpulkan bahwa pendidikan nilai yang berhasil adalah pendidikan yang dapat membangun karakter subjek didik sebagai orang yang dapat memahami nilai-nilai moral 
(moral knowing), merasakan nilai-nilai moral (moral feeling) dan melaksanakan nilai-nilai moral (moral action) dalam kehidupannya. Dari kesemua aspek itu, tujuan terakhir pendidikan nilai adalah realisasi nilai-nilai moral dalam diri peserta didik.

Sosok guru sebagai pendidik moral atau karakter adalah guru yang kaya hati (Hidayatullah, 2010: 152-153). Artinya, guru harus memiliki jiwa yang besar, lapang dada dan sabar dalam menghadapi siswa. Yang pertama kali dilakukan guru dalam pendidikan moral adalah mengetuk dan menyentuh hati para peserta didiknya. Guru mengajar dengan melibatkan hatinya. Sekiranya guru bersikap keras lagi berhati kasar, tentulah siswa akan menjauhinya. Kompetensi penting dalam pendidikan adalah membangun hubungan interpersonal berupa komunikasi yang terjalin baik. Dalam hal ini, guru-guru cenderung menjadi fasilitator, mediator, bukan birokrat. Darmiyati Zuchdi (2009: 35). mengatakan bahwa pendidikan nilai (moral) memerlukan berbagai pendekatan yang oleh Kirschenbaum disebut pendekatan komprehensif, yang dinilai dapat memberikan pemecahan masalah yang relatif lebih tuntas dibandingkan dengan pendekatan tunggal. Menurut Kirschenbaum (1995: 6), istilah komprehensif dalam pendidikan nilai mencakup berbagai aspek dalam satu kesatuan, yaitu isi pendidikan nilai, metode, proses, pendidik, dan evaluasinya

Isi pendidikan nilai meliputi semua permasalahan yang berkaitan dengan pilihan nilai-nilai yang bersifat pribadi sampai pertanyaan-pertanyaan etika secara umum. Metode pendidikan nilai meliputi inkulkasi nilai, keteladanan, fasilitasi keputusan moral secara bertanggung jawab, dan keterampilan hidup yang lain. Pendidikan nilai di sekolah hendaknya terjadi dalam keseluruhan proses pendidikan di kelas, dalam kegiatan ekstrakurikuler, dalam proses bimbingan dan penyuluhan, dalam upacara-upacara pemberian penghargaan, dan semua aspek kehidupan. Pendidikan nilai di masyarakat terjadi melalui kehidupan dalam masyarakat. Orang tua, lembaga keagamaan, penegak hukum, polisi, organisasi kemasyarakatan, semua perlu berpartisipasi dalam pendidikan nilai. Merekalah yang menjadi pendidik nilai, bukan hanya guru di sekolah. Konsistensi semua pihak dalam melaksanakan pendidikan nilai memengaruhi kualitas moral generasi muda.

Di samping isi, metode, pendidik, dan prosesnya, pendidikan nilai juga memerlukan evaluasi yang komprehensif. Evaluasi dilakukan untuk mengetahui ketercapaian tujuan. Tujuan pendidikan nilai meliputi tiga kawasan, yakni penalaran nilai/moral, perasaan nilai/moral dan perilaku nilai/moral. Maka, evaluasi pendidikan nilai juga mencakup tiga ranah tersebut. berupa evaluasi penalaran moral, evaluasi karakteristik afektif, dan evaluasi perilaku (Darmiyati, 2010: 51). Muara dari pendidikan nilai adalah terbentuknya karakter peserta didik yang teraktualisasi dalam perilaku hidupnya sehari-hari.

Penelitian-penelitian terdahulu telah mengungkap bahwa anak usia dini yang bersekolah di Taman Kanak-Kanak dapat menerima dan memahami pendidikan nilai-nilai dengan beragam media dan metode. Penelitian Mami Hajaroh, dkk (2013, 2014) menyimpulkan bahwa model pendidikan karakter melalui lagu dan dolanan telah diikembangkan dan didifusikan di Taman kanak-Kanak, khususnya TK 'Aisyiyah DIY. Penelitian ini mengklarifikasi nilai-nilai karakter yang terkandung di dalam praktik pembelajaran lagu dan dolanan tradisional Jawa pada anak usia dini di Taman KanakKanak.

Penelitian Chou, Mei-Ju, Yang, Chen-Hsin, Huang, Pin-Chen (2014) menyatakan bahwa pendidikan anak usia dini di Taiwan dipandang sangat penting dalam upaya mengembangkan karakter anak, khususnya di dalam panduan kurikulum ditegaskan bahwa pendidikan karakter harus dimulai sedini mungkin. Penelitian Chou, dkk, bertujuan untuk mengetahui lebih mendalam arti penting pendidikan karakter dari perspektif pendidikan usia dini dan dampaknya terhadap hubungan orangtua dan anak, khususnya dalam keluarga yang multicultural. Hasil penelitian menyimpulkan pendidikan karakter pada anak usia dini dapat memperdalam ikatan antara orang tua dan anak-anak. Dukungan dan peran orang tua anak usia prasekolah dalam mendongeng, bermain, musik dan seni anak-anak adalah faktor penting dalam hubungan orangtua-anak anak prasekolah. Pemerintah Taiwan memberi tanggungjawab kepada setiap institusi penyelenggara pendidikan, baik itu formal maupun nonformal untuk menanamkan pendidikan karakter.

Wawancara kepada dua orang Kepala TK yang ada di Banjarmasin menyimpulkan mereka menanamkan pendidikan nilai-nilai moral dalam proses belajar mengajar di sekolah. Perlu dilakukan penelitian secara lebih mendalam dan menyeluruh terkait pendidikan nilai moral anak di Taman 
Kanak-Kanak di Banjarmasin. Permasalahan yang diteliti antara lain: (1) Apa saja nilai-nilai karakter yang dijadikan nilai target di dalam penddidikan karakter di Taman Kanak-Kanak di Banjarmasin? (2) Bagaimanakah metode internalisasi nilai karakter yang diterapkan dalam internalisasi pendidikan karakterr di Taman Kanak-Kanak di Banjarmasin? (3) Bagaimana hasil pendidikan nilai karakter anak usia dini di Taman Kanak-Kanak di Banjarmasin?

\section{METODE PENELITIAN}

Penelitian ini menggunaan pendekatan kualitatif dengan jenis penelitian deskriptif untuk menggali informasi lebih dalam mengenai pendidikan nilai-nilai moral di Taman Kanak-Kanak yang dipraktikkan oleh guru di Banjarmasin. Setting penelitian adalah 30 Taman Kanak-Kanak 'Aisyiyah di kota Banjarmasin. Subjek penelitian adalah guru-guru TK "Aisyiyah di Kota Banjarmasin sebanyak 30 orang, dan 1 orang Ketua Majelis Dikdasmen Pimpinan Wilayah 'Aisyiyah Kalimantan Selatan.

Teknik pengumpulan data yang digunakan adalah focus group discussion (FGD). FGD dilaksanakan di Kator Pimpinan Wilayah 'Aisyiyah Kalimantan Selatan, Jalan Perdagangan, Banjarmasin, Kalimantan Selatan. Pedoman FGD digunakan untuk instrument pengumpulan data meliputi urgensi pendidikan moral di TK, nilai-nilai moral yang dikembangkan, setting/suasana pembelajaran yang dirancang, metode pendidikan moral yang diterapkan, evaluasi pendidikan moral yang dilaksanakan, dan hasil pendidikan yang telah dicapai. FGD direkam menggunakan alat perekam digital kemudian dilakukan transkripsi atas rekaman tersebut dalam bentuk file MS Word.

Setelah data hasil FGD dalam file MS Word terkumpul seluruhnya, dilakukan analisis dengan teknik analisis kualitatif interaktif model Miles \& Huberman ('1994), dengan tahap-tahap: reduksi data, penyajian data, dan penarikan kesimpulan. Data yang relevan dengan pertanyaan penelitian dianalisis dan dirangkai dalam proposisi-proposisi menjadi deskripsi yang saling terkait antara komponen satu dengan komponen lainnya. Dengan demikian diperoleh pemahaman yang terpadu tentang pendidikan moral anak di Taman Kanak-Kanak 'Aisyiyah yang telah dipraktikkan oleh para guru di kota Banjarmasin. Keabsahan data dalam penelitian ini menggunakan triangulasi sumber. Berbagai data yang sama dan saling mendukung dari berbagai sumber (subjek) dipandang sebagai data yang valid dan selanjutnya disajikan secara deskriptif dan disimpulkan.

\section{HASIL DAN PEMBAHASAN}

\section{Hasil Penelitian}

1. Nilai-nilai Moral yang Dikembangkan

Nilai-nilai moral yang dikembangkan di Taman Kanak-Kanak oleh guru-guru di Banjarmasin pada intinya sama karena sekolah menerapkan kurikulum yang sama secara terpusat. Hanya saja, ada perbedaan pandangan mengenai nilai-nilai utama yang seharusnya dikembangkan di Taman Kanak-Kanak menurut persepsi/pendapat guru. Secara empiris, nilai-nilai yang dikembangkan di sekolah adalah sebagai berikut.

a. Nilai religius:

Nilai utama yang dikembangkan adalah nilai religius. Guru-guru sepakat nilai religius penting sebab bangsa Indonesia adalah bangsa yang berKetuhanan Yang Maha Esa. Agama memegang peran penting dan menjadi pedoman manusia dalam menjalani kehidupan sehingga nilainilai religius dikenalkan sejak dini terutama pengenalan agama dan ayat-ayat suci yang pendek serta doa sehari-hari sesuai dengan ajaran agama yang dianut oleh anak. Di lingkunganTaman KanakKanak yang sekaligus menjadi pesantren, anak-anak TK sudah dilatih untuk beribadah rutin, berdoa dan menghafal Alquran sejak masuk pertama ke pesantren. Kompetensi yang ditargetkan adalah menghafal hadis Nabi Muhammad Saw (hadis pendek, tidak yang panjang), dapat membaca Iqra sampai minimal jilid 5 dan membaca doa-doa sehari-hari seperti doa sebelum dan sesudah makan, doa ketika akan tidur dan bangun tidur, doa belajar, doa menaiki kendaraan, doa bepergian, doa memakai baju, dsb.

b. Nilai kemandirian

Setelah nilai religius, nilai yang paling ditekankan di Taman Kanak-Kanak adalah kemandirian. Sesuai dengan tingkat perkembangan anak usia dini, kemandirian yang dimaksud 
adalah mengerjakan hal-hal yang sederhana seperti mandi sendiri, makan sendiri, memakai baju dan sepatu sendiri. Juga dibiasakan anak mengemasi barang-barangnya sendiri sebelum pulang sekolah. Guru membekali anak-anak dengan nasehat agar di rumah mereka juga belajar mandiri untuk kegiatan-kegiatan yang sama seperti di sekolah.

c. Nilai keberanian

Guru-guru juga setiap hari mengembangkan nilai keberanian dan atau percaya diri dalam diri peserta didik. Guru membiasakan anak untuk tampil di muka umum pada berbagai kesempatan seperti pentas seni, kunjungan edukasi, dan sebagainya. Demikian pula dalam pembelajaran di luar kelas, guru juga memfasilitasi anak untuk mengikuti kegiatan outbond yang salah satu tujuannya adalah anak akan menjadi berani dan percaya diri.

d. Nilai kejujuran:

Menurut para guru, nilai kejujuran juga menjadi nilai utama. Kejujuran sangat penting diajarkan dan dibiasakan agar generasi bangsa menjadi orang jujur. Apabila menjadi pejabat, mereka tidak korupsi. Terlebih lagi Indonesia masih termasuk bangsa yang belum bebas dari korupsi.

e. Nilai toleransi:

Selain itu, anak-anak dididik dengan nilai toleransi walaupun mereka dididik di TK Islam, mengingat keragaman Indonesia. Toleransi juga dibiasakan ketika bermain sehingga anak mau menerima perbedaan.

f. Nilai disiplin

Nilai disiplin dibiasakan agar terbawa sampai besar nanti. Disiplin ketika datang ke sekolah (harus tepat waktu), disiplin dalam mengantri ke kamar mandi, disiplin ketika masuk kelas, disiplin dalam mengambil dan meletakkan mainan di tempat semula.

g. Nilai peduli sosial

Menurut para guru, nilai peduli social dikembangkan dengan pembiasaan di sekolah. Dengan mengembangkan nilai peduli sosial akan tumbuh empati dalam diri anak, akan rendah hati dan tidak sombong, dan mau berbagi dengan temannya, baik mainan maupun makanan. Peduli sosial juga diterapkan dengan mengajak anak-anak mengunjungi temannya yang sedang sakit di rumahnya.

h. Nilai respek dan sopan santun

Nilai ini penting dibiasakan, yaitu sopan santun kepada orang tua, orang yang lebih tua, guru dan teman. Nilai respek (menghormati orang lain), tidak membeda-bedakan teman. Anak harus mau bermain dengan semua teman. Anak dilarang membuli temannya. Menurut para guru, anakanak umumnya telah mengenal dan menginternalisasikan nilai sopan santun dan respek, terutama kepada guru-gurunya. Buktinya, ketika mereka sudah berada di SMP atau SMA masih sering dating ke TK untuk meminta doa agar mereka lulus ujian nasional. Hal tersebut sangat mengharukan bagi para guru TK. Mereka tidak menyangka anak-anak didiknya masih ingat pada gurunya dulu.

i. Nilai kesabaran

Guru telah membiasakan dan melatih anak agar bersabar dalam segala hal, tidak boleh tergesa-gesa dan cepat marah. Walaupun melatih kesabaran itu sangat sulit untuk anak usia dini, khususnya di Taman Kanak-Kanak, tetapi guru tetap membiasakan terutama bila ada anak-anak yang berkelahi. Masalah ini menjadi tantangan tersendiri bagi guru TK.

Dari hasil diskusi terfokus dapat disimpulkan bahwa berbagai nilai telah dikembangkan guru di Taman Kanak-Kanak. Ada Sembilan nilai utama yang menjadi materi pendidikan moral seharihari di Taman Kanak-Kanak, yaitu nilai religiusitas, kemandirian, keberanian (percaya diri), kejujuran, , disiplin, toleransi, empati/peduli social, respek/sopan santun dan kesabaran.

\section{Metode Pengembangan Moral}

Ada berbagai macam metode yang digunakan guru di Taman Kanak-Kanak baik di Banjarmasin. Secara umum, semua guru mengatakan mereka telah terbiasa menggunaka metode yang bervariasi, terutama metode yang bersifat learning by doing, ada contoh yang dapat ditunjukkan. Dari hasil FGD dapat diketahui bahwa metode yang bervariasi tersebut adalah sebagai berikut. 


\section{a. Keteladanan}

Sebagaimana telah dinyatakan terdahulu bahwa guru sangat memahami perannya sebagai teladan bagi siswa. Keteladanan guru Taman Kanak-Kanak sangat penting untuk pengembangan moral anak dirinya. Menyadari pentingnya keteladanan, guru dalam tingkah laku sehari-hari telah berusahan menunjukkan keteladanan tersebut, misalnya guru datang lebih awal daripada siswanya, dan menyambut siswa di depan pintu gerbang sekolah, guru berbicara sopan dan penuh tata karma, guru menunjukkan kasih sayang dan perhatian yang sama pada semua siswa walaupun ada siswanya yang berkebutuhan khusus. Guru mengajak siswa untuk berempati dan siap menolong anak yang berkebutuhan khusus di kelasnya.

b. Pembiasaan

Pembiasaan merupakan metode yang sehari-hari dilakukan guru. Sesuai dengan tingkat usia perkembangan peserta didik, metode pembiasaan menjadi metode andalan semua guru TK. Pembiasaan diyakini oleh semua guru sangat penting karena pendidikan moral merupakan proses yang lama. Peserta didik harus dibiasakan dengan berbagai kegiatan yang diharapkan akan terinternalisasi secara perlahan-lahan dalam dirinya. Pembiasaan yang telah dilakukan guru adalah sebagaimana tampak pada Tabel 1 .

Tabel 1. Pembiasaan yang dilakukan guru TK 'Aisyiyah di Banjarmasin

\begin{tabular}{|c|c|c|c|}
\hline No. & Pembiasaan & Kegiatan & Nilai Moral \\
\hline 1. & Berdoa & $\begin{array}{l}\text { Sebelum dan setelah belajar, } \\
\text { sebelum dan sesudah makan, } \\
\text { sebelum dan sesudah tidur, } \\
\text { mendoakan orang tua, bepergian, } \\
\text { memakai baju, becermin, dsb. }\end{array}$ & religius \\
\hline 2. & Sholat & Sholat Dhuha berjamaah & religius \\
\hline 3. & Mencuci tangan & $\begin{array}{l}\text { Sebelum dan sesudah makan, } \\
\text { sebelum dan sesudah bermain }\end{array}$ & disiplin, bersih \\
\hline 4 & Antri & $\begin{array}{l}\text { Mengambil makanan, mengambil } \\
\text { mainan, ke kamar mandi }\end{array}$ & disiplin, respek \\
\hline 5. & Unjuk kebolehan & $\begin{array}{l}\text { Pentas seni, sosio drama, } \\
\text { panggung boneka }\end{array}$ & $\begin{array}{l}\text { berani, percaya } \\
\text { diri }\end{array}$ \\
\hline 6. & Melakukan kegiatan pribadi & $\begin{array}{l}\text { Makan, minum, mandi, memakai } \\
\text { baju dan sepatu. }\end{array}$ & mandiri \\
\hline 7. & Mengucapkan terima kasih & $\begin{array}{l}\text { Ketika peserta didik mendapatkan } \\
\text { sesuatu dari orang lain }\end{array}$ & $\begin{array}{l}\text { respek, } \\
\text { santun }\end{array}$ \\
\hline 8. & Mengucapkan tolong & $\begin{array}{l}\text { Ketika peserta didik ingin } \\
\text { mendapatkan bantuan }\end{array}$ & $\begin{array}{l}\text { respek, } \\
\text { santun }\end{array}$ \\
\hline 9. & Mengucapkan maaf & $\begin{array}{l}\text { Ketika peserta didik berkelahi, } \\
\text { berbuat salah }\end{array}$ & $\begin{array}{l}\text { respek, sopan } \\
\text { santun }\end{array}$ \\
\hline 10. & Mengunjungi teman sakit & $\begin{array}{l}\text { Berkunjung ke rumah teman } \\
\text { sekelas yang sakit }\end{array}$ & respek, peduli \\
\hline
\end{tabular}

\section{c. Pemberian Nasehat}

Setiap hari guru memberikan nasehat bila waktu sekolah hampir berakhir. Anak-anak diingatkan agar setelah sampai ke rumah segera membuka sepatu, meletakkannya di rak sepatu, berganti pakaian rumah, cuci tangan sampai bersih, makan dengan berdoa di awal dan akhir, bermain tetapi tidak melupakan salat, membantu pekerjaan orang tua di rumah, tidur tidak boleh larut malam, bangun pagi tidak boleh terlambat. Guru juga memberi nasehat jika ada kejadian yang tidak diinginkan misalnya: ada anak yang berkelahi dan menangis. Anak dilerai agar jangan berkelahi, diberi nasehat untuk hidup rukun, dan didamaikan dengan saling meminta maaf dan bersalaman. d. Bercerita.

Guru-guru sering menggunakan metode bercerita untuk mengembangkan moral anak, seperti bercerita dalam acara tutup tahun. Bercerita merupakan salah satu metode utama yang paling banyak digunakan oleh para guru TK. 
e. Tanya jawab

Guru melakukan tanya jawab setiap hari untuk mengembangkan kemampuan berbahasa sehingga anak dapat berkomunikasi dengan baik. Dari sisi moral, tanya jawab dilakukan untuk melatih anak berani mengeluarkan ide dan pendapatnya sehingga anak menjadi orang yang percaya diri. Tanya jawab biasanya dilakukan dalam kegiatan pembelajaran dan setelah mengunjungi tempat-tempat tertentu di luar (out door activity).

f. Bernyanyi

Bernyanyi merupakan salah satu metode penanaman nilai moral yang utama dilakukan guru. Lagu-lagu yang diciptakan untuk anak-anak biasanya sederhana dan syairnya mengandung ajaran moral seperti lagu "Jangan Buang Sampah Sembarang Tempat" (ajaran moral kebersihan), Lagu "Bangun Tidur" (ajaran moral kemandirian), lagu "Tuhanku" (ajaran moral religius), dan banyak lagi. Kebanyakan lagu-lagu yang diajarkan adalah lagu-lagu Islami.

g. Pengenalan dan hafalan hadis singkat

Taman kanak-kanak 'Aisyiyah di Banjarmasin berbasis pendidikan Islam sehingga guru wajib mengenalkan hadis-hadis Nabi Muhammad Saw dan maknanya. Hadis yang dikenalkan adalah hadis singkat (pendek). Selain itu anak-anak juga dianjurkan untuk menghafal hadis singkat tersebut, misalnya hadis tentang akhlak, hadis tentang marah, hadis tentang kebersihan, hadis tentang salat, dan sebagainya.

h. Bermain peran (sosiodrama)

Salah satu metode penanaman nilai moral yang menyenangkan adalah sosiodrama. Anak dengan arahan guru bermain peran pada kegiatan belajar tertentu, seperti pada tema profesi, misalnya dokter. Ada anak yang menjadi dokter dan ada yang menjadi pasien, serta ada pula yang menjadi perawat.. Diharapkan dengan bermain peran, anak-anak akan menghayati peran polisi sebagai profesi mulia. Anak akan terinspirasi untuk menjadi orang yang baik, taat pada aturan yang telah ditetapkan oleh masyarakat dan negara. Menurut para guru, metode bermain peran lebih mengena karena langsung praktik bersama teman sehingga keterampilan komunikasi dan sosial anak menjadi semakin baik.

i. Wisata pendidikan

Semua guru mengatakan bahwa mereka telah merancang wisata pendidikan setiap tahun. Wisata ini ada yang dilaksanakan per sekolah, tetapi ada pula yang dikoordinasikan bersama dengan TK lainnya di bawah kepengurusan IGABA (Ikatan Guru 'Aisyiyah Bustanul Athfal). Umumnya anak-anak dibawa ke tempat-tempat rekreasi dan tempat fasilitas umum.

j. Fasilitasi Nilai

Selain pembiasaan sehari-hari, guru juga menyediakan berbagai fasilitas agar anak lebih mudah mempraktikkan perilaku bermoral secara efektif, misalnya guru menyediakan kotak amal yang harus diisi oleh siswa setiap hari Jumat. Uang yang terkumpul secara berkala disumbangkan kepada pihak-pihak yang membutuhkan.

Ada pula fasilitasi tempat sampah dan arena bermain sehingga anak dapat mengaktualisasikan nilai-nilai yang telah diajarkan melalui nasehat menjadi lebih berdaya guna. Sedangkan arena bermain yang bersifat kelompok disediakan di banyak TK agar sejak dini anak sudah terbiasa untuk bersosialisasi dan bekerja sama. Ada pula fasilitas untuk beribadah, yaitu mushola. Anak-anak dibiasakan untuk salat Dhuha di mushola sekolah. Dari uraian di atas dapat disimpulkan bahwa guru taman kanak-kanak telah menggunakan sepuluh metode untuk mendidik moral anak usia dini yang menjadi tanggung jawabnya.

\section{Hasil pendidikan moral}

Guru menilai bahwa anak-anak didiknya telah mencapai perkembangan moral yang sangat berarti selama dua tahun dididik di Taman Kanak-Kanak. Perubahan yang paling tampak adalah kemandirian dan rasa percaya diri anak serta respek (sopan santun). Pada awal masuk, anak-anak sering menangis, merasa takut, tetapi berubah ketika sudah berada di kelas B. anak-anak berani tampil, mandiri dalam mengurus dirinya, dapat berkomunikasi dengan sopan, koordinasi fisik sudah bertambah baik, berangkat sekolah sendiri tanpa diantar orang tua (siswa yang rumahnya dekat 
dengan sekolah). Dari sisi nilai religius, yang sudah terwujud adalah anak sudah dapat menghafal surat-surat pendek dalam kitab suci Alquran (juz amma) dan sudah dapat menghafal 20 hadis singkat.

Para guru juga sepakat bahwa pendidikan moral yang dilakukannya di taman kanak-kanak telah berhasil terutama dalam nilai religius, nilai percaya diri, dan nilai respek. Bahkan ketika anak sudah berada di jenjang sekolah yang lebih tinggi, anak sering datang ke sekolah untuk bertemu gurunya. Demikian pula ketika akan menghadapi ujian nasional SMA, banyak anak didik yang datang ke sekolah untuk meminta doa agar mereka berhasil di dalam menempuh ujian nasional. Hal tersebut menunjukkan bahwa pendidikan moral yang dikembangkan guru di sekolah telah membekas dalam diri siswa sampai ia menjadi remaja. Mereka tetap hormat dan menyayangi guru TK mereka. Menurut peneliti, temuan ini sangat menarik. Dari perilaku siswa tersebut dapat disimpulkan bahwa pendidikan karakter hormat kepada guru sudah menjadi kebiasaan (habit) dalam diri peserta didik ketika ia telah remaja dan dewasa. Tak dapat dipungkiri, kebiasaan demikian tentu didukung oleh semua guru dan pendidik, termasuk orang tua siswa sehingga nilai hormat kepada guru tetap melekat dalam diri peserta didik dan menjadi ciri khas kepribadiannya.

\section{Pembahasan}

Berdasarkan hasil penelitian telah diketahui bahwa ada delapan nilai moral yang dikembangkan oleh guru di Taman Kanak-Kanak di Banjarmasin adalah religiusitas, kemandirian, percaya diri, kejujuran, disiplin, peduli sosial, respek. Anak usia dini telah dikenalkan dan dibiasakan untuk bertingkah laku sesuai dengan nilai-nilai tersebut dengan menggunakan metode yang bervariasi melibatkan pikiran, perasaan, dan perbuatan. Apa yang dilakukan oleh guru telah sesuai dengan pendapat Lickona (2014) bahwa dalam pendidikan moral atau pendidikan karakter harus mencakup tiga aspek, yaitu pengetahuan moral (moral knowing), perasaan moral (moral feeling) dan tindakan moral (moral action).

Dalam perspektif Kirschenbaum (1995), ada empat rumpun metode pendidikan moral, yaitu keteladanan, inkulkasi, fasilitasi, dan keterampilan nilai. Para guru telah menggunakan tiga metode dengan berbagai strateginya, yaitu keteladanan, inkulkasi, dan fasilitasi. Hanya metode keterampilan nilai saja yang belum dilaksanakan guru sebab yang dididik adalah anak usia dini sehingga belum tepat menggunakan metode keterampilan nilai. Metode inkulkasi mendapatkan porsi yang lebih besar di dalam pendidikan moral anak, terutama strategi pembiasaan nilai-nilai moral. Pembiasaan merupakan upaya menginternalisasikan nilai-nilai moral melalui berbagai kegiatan rutin sehingga nilai-nilai moral tersebut akan menjadi bagian tak terpisahkan dari pribadi anak. Hal tersebut sejalan dengan pendapat Molchanov (2013: 616) bahwa pengembangan moral dapat dipandang sebagai proses pengembangan dari pengaturan tingkah laku yang berdasarkan pada internalisasi sistem norma. Melalui proses pembiasaan anak lama kelamaan akan memiliki kebiasaan (habit) baik yang disenanginya. Anak sudah menyadari sepenuhnya dan bersikap setuju mengapa perilaku baik tersebut harus dilakukan. Sejalan dengan pendapat tersebut, Goodman (2018:8) mengatakan bahwa nilai-nilai kebaikan (virtues) tidak hanya berkontribusi untuk meningkatkan kualitas kehidupan, tetapi lebih dari itu. Nilai-nilai moral harus dimiliki oleh setiap orang bukan sekedar jalan untuk mencapai tujuan, melainkan adalah untuk mewujudkan kehidupan yang baik dan meninggikan martabat manusia. Usaha ini tentu saja harus dimulai sejak awal, yaitu sejak anak usia dini. Demikian pula pendapat Ki Hadjar Dewantara bahwa dengan pendidikan moral yang baik, kodrat bawaan anak yang tidak baik akan tergantikan dengan tabiat yang baik melalui proses pembiasaan, dorongan dan perhatian yang terus menerus dari guru kepada anak.

\section{SIMPULAN}

Ada sembilan nilai karakter yang dikembangkan guru, yaitu religiusitas, kemandirian, keberanian, kejujuran, toleransi, disiplin, peduli sosial, respek/sopan santun, dan kesabaran. Guruguru belum banyak melaksanakan pembelajaran di luar kelas seperti ke museum, tempat rekreaasi, dan fasilitas umum yang bernilai edukatif. Metode yang digunakan guru adalah keteladanan, pembiasaan, memberi nasehat, bercerita dan sosiodrama, tanya jawab, wisataa pendidikan, bernyanyi, pengenalan dan hafalan hadis singkat. Guru telah berhasil mengembangkan nilai-nilai karakter anak usia dini diTaman Kanak-Kanak di Banjarmasin dan tetap melekat dalam diri anak walaupun anak tersebut telah menjadi remaja. 


\section{DAFTAR PUSTAKA}

Chou, Mei-Ju, Yang, Chen-Hsin, Huang, Pin-Chen. (2014). The Beauty of Character Education on Preschool Children's Parent-Child Relationship. CY-ICER 2014. Procedia - Social and Behavioral Sciences. 143, 527 - 533.

Dewantara, K. H. (1977). Pendidikan (Education). Yogyakarta: Majelis Luhur Taman Siswa.

Goodman, Joan. (2018). Searching for character and the role of schools. Ethics and Education Journal. October 2018. DOI.10.1080/17449642.2018.1537989.

Hifayatullah, F. (2010). Guru yang Berkarakter. Surakarta: UNS Press

Kirschenbaum, H. (1995). 100 ways to enhance values and morality in school and youth settings. Boston: Allys and Bacon.

Lickona, Thomas. (1991). Educating for character - How our schools can teach respect and responsibility. New York: Bantam Books.

Lovat, T. "Values Education as good practice pedagogy: Evidence from Australian empirical research" Journal of Moral Education. Routledge Taylor \& Francis Group. Vol. 46. No. 1. March 2017. 88-96.

Miles, B. Mathew dan Michael Huberman. (1992). Analisis Data Kualitatif. Jakarta: UI Press.

Mami Hajaroh, dkk. (2014). "Pengembangan Model Indikator Sekolah Ramah Anak di Kota Yogyakarta”. Laporan Penelitian. Yogyakarta: FIP UNY.

Undang-Undang Nomor 20 Tahun 2003 tentang Sistem Pendidikan Nasional.

Zuchdi, darmiyati. (2010). Humanisasi Pendidikan. Jakarta: Penerbit Bina Aksara. 